\title{
The online consumer behavior outside Java Island: A case study of Lazada Indonesia
}

\author{
Winarko, Hilarius Bambang $₫$ \\ Management Department, Sampoerna University, Indonesia (b_winarko@yahoo.com) \\ Manshur, Anis Thoha \\ Marketing \& Business Development, Kofera Technology, Indonesia (anisthoha@gmail.com)
}

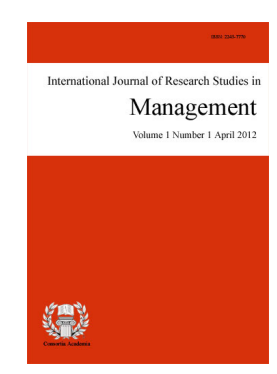

ISSN: $2243-7770$ Online ISSN: 2243-7789

\section{Abstract}

Indonesia has become a grow developing country with more than 260 million of people in size and 132 million Internet subscribers are interconnected. The Internet penetration and the number of online shoppers in Indonesia continues to grow significantly. This study aimed to analyze online consumer behavior outside Java Island based-on Lazada Indonesia' case, in-order to provide solutions to reach new target markets in each province. The study was using online survey method and descriptive statistics analysis which used Lazada Indonesia's customers and non-customer as the target respondents. Some variables such as online shopping motivation, media accessed, product category preferences and other variables associated with online shopping were included in the research. The results indicated a significant growth in mobile device purchases by online shopping and high demand in fashion product categories. Digital marketing efforts would also become important tools in online marketing activities.

Keywords: e-commerce; digital marketing; online consumer behavior; online retailing; online shopping 


\section{The online consumer behavior outside Java Island: A case study of Lazada Indonesia}

\section{Introduction}

The concept of electronic commerce (e-Commerce) grew up in the dynamics of information, technology and communication era. However, the rapid rise of the Internet has made the potential of e-Commerce becoming more promising than before (Mannisto, 1999). Indonesia is a developing country that has prospective consumer demographic due its huge population that reaches more than 260 million in 2017. High Internet penetration in Indonesia had triggered the growth of e-Commerce industry. In 2012, Indonesia had 63 million people online, which grew up to 132 million people online in 2016 according to Indonesia Internet Service Provider Association (APJII). This phenomenon calls the raise of electronic commerce companies in Indonesia, among them are Lazada.co.id, Blibli.com, Elevania.co.id, Shopee.co.id, JD.id and many others. This emerging e-Commerce industry creates more employment opportunities including its market expansions from Java island's captive market where the main population is located, which later may lead fierce competitions of the industry.

\subsection{Lazada}

Lazada Indonesia (www.lazada.co.id) was founded by a German incubator company Rocket Internet GmbH and represented in Indonesia by PT. Ecart Services Indonesia in 2012. The company's business model are Business-to-Consumer (B2C) and Business-to-Business-to-Consumer (B2B2C) online retailer that sells smartphones, laptops, electronics, and household decor to health and beauty products. Its structure consists of $55 \%$ B2BC (marketplace/retail platform) and 45\% B2C. This business model was working well, making the company to be a pioneer and leader in online retailing in less than two years. Moreover, there were 60,000 Stock Keeping Unit (SKU) in more than 5,000 categories. One of Lazada Indonesia's important efforts is to give the best service for customer by offering special deals, best price guarantee and provides the simplicity of transaction featuring free shipping, cash on delivery and official warranty for each product.

Not only in Indonesia, Lazada was also present in other Southeast Asia countries, such as: Malaysia, Vietnam, Philippines, Thailand and Singapore. There was a report states that Lazada Group got valuable investment worth of USD250 million from UK-based chain store Tesco, Access Industries, Investment AB Kinnevik, and Verlinvest (Venturebeat.com, 2013). Total investment received by Lazada Group was around USD436 million that come from Tesco, Access Industries, Investment AB Kinnevik, Verlinvest, HV Holtzbrinck Ventures, Summit Partners and Tengelmann Ventures (Crunchbase, 2014). CEO Maximilian Bittner once said it aimed to become the Amazon of South East Asia (Sharma, 2013). And finally in April 2016, an e-Commerce giant Alibaba agreed to acquire controlling interest in Lazada Group.

\subsection{Demographics}

Indonesia is the fourth largest country in the world; it is just behind China, India and the US. As an archipelago country, Indonesia consists of more than 17,000 islands. Based on Indonesia Statistics Agency (BPS)'s forecasting, Indonesia population may grow to more than 260 million people in 2017. In 2010, there was $49.79 \%$ urban population and 50.21\% rural population. Urban population has increased by $42 \%$ from 2000.

Young people dominate Indonesia population. It can be seen from Indonesia population age group pyramid as reported by the Central Intelligence Agency's World Fact book in 2014. The age structure are 26.2\% (0-14 years), $17.1 \%$ (15-24 years), $42.3 \%$ (25-54 years), 6.5\% (55-64 years) and 6.4\% (65 years and over). The median age is 29.2; it means most of Indonesian people are young people. The country enjoy a diversified ethnic groups. Javanese is a major ethnic in Indonesia, it has $41.71 \%$ of the total population in Indonesia. Most of Javanese ethnic live in central part of Java and eastern part of Java, meanwhile the second largest ethnic is Sundanese, 
who lives in western part of Java.

Many Indonesian people live in capital regions, including Jakarta capital city, which is located in Java island where more than 10 million people stay in. Jakarta is not only the most populous city in Indonesia but also ranked $13^{\text {th }}$ as most populated cities in the world. Moreover, the official metropolitan larger area that being called as Jabodetabek (Jakarta, Bogor, Depok, and Tangerang) is the second largest population in the world. Jakarta is also one of the fastest-growing cities in the world with population density 15,342 people per square kilometer (39,740/square mile). The largest population in outside Java Island is Medan (North Sumatra's capital city) that has around 2 million people lives in that city, followed by Palembang which is the second largest city with the population of 1.4 million people.

The average salary above USD 160 comes from people who work in Papua, East Kalimantan, Riau Islands and Jakarta provinces. And according to Indonesia Statistics Agency (BPS-Statistic Indonesia), Papua, East Kalimantan and Riau Islands provinces have higher average salary compared to others because the living cost are relatively higher. The second reason is that the provinces like Papua, East Kalimantan, and Riau Islands are well-known as mining areas, whereby mining workers are considered as middle-up class people who have higher salaries than other industry sectors on-average.

\subsection{Consumer Spending}

A report from Boston Consulting Group (BCG) shows that there are 74 million Indonesian people who have household expenditure of more than USD 160 in 2012. Those groups of people are belongs to middle-class and affluent consumer (MAC) socioeconomic category. Further, by 2020, BCG predicts that Indonesia will have 141 million MACs with assumption 8 to 9 million people will enter the middle class each year. It is one signal Indonesia's economy is growing rapidly since large portion of the population is entering the middle-class and affluent consumer (MAC) socioeconomic category. Middle-class consumers are typically confident in spending home goods, vehicles, consumer durables, and financial services. In this report, monthly household-expenditure numbers are stated in real 2011 terms (adjusted for inflation) and include regular household, such as food, utilities, transportation, communication, and regular household supplies, and exclude discretionary spending such as entertainment, restaurant dining, and similar categories. The expenditure level is based-on the data taken from BPS, which use regression analysis to remove irregular expenditures. The spending levels used to define wealth classes in this model may differ from those used by market research agencies to define socioeconomic status levels because of different data-collection methodologies and models.

\subsection{The Internet}

The growth of Internet user in Indonesia was relatively fast too. The number of Indonesia Internet users rise 22\% from 62 million in 2012 to be 74.57 million in 2013. A market research company, Markplus Insight and its online magazine Marketeers conducted comprehensive research about Netizen in Indonesia. A netizen is defined as someone who spends at least three hours online per day. In 2013, there were 31.7 million Netizens or it increased 2.82\% from 24.2 million in 2012. And thus the Internet becomes the most accessed media by this Netizen. As the Internet penetration is growing, many people find informations and access news through the Internet. Based on Markplus survey, 97.8\% Netizen prefers to acess from Internet as their online communication medium.

Only few years ago, Indonesia's mobile and the Internet markets were dominated by the under-25s. Energetic and talkative, they made Indonesia as the social media capital of the world. The problem was, they did not spend much money online, in large part because most of under-25s do not have much money to spend. As everyone would expect in a country where the average age is 28 , the typical Indonesian Internet user is a young, tech-savvy city dweller. Therefore, it is a surprise to learn that the most rapid growing in Internet users is currently coming from the $30+$ age groups and the secondary cities. Experts believe that this would bring great 
news for technology investors, because the marketing moves away form its past obsessions with simple free entertainment and Social Media chatting into an e-Commerce, paid online content and Business-to-Business (B2B) services (Redwing-asia, 2013). As the consequence, the use of smartphone for accessing the Internet is also increasing as well.

\subsection{Logistic}

In terms of logistic performance, Indonesia may still lag behind from the other Asia's countries such as Singapore, China, Japan, Thailand and Malaysia. Singapore has the best logistic performance due-to its excellent infrastructure and higher Logistic Performance Index. The biggest problem of logistic in Indonesia is poor infrastructure, it shown from the lower score in infrastructure, which is 2.92 out of 5 . The development of infrastructure in Indonesia is not so fast and is not equally distributed to all regions in Indonesia. It might be happened since Indonesia by nature is an archipelago country which has many islands. Therefore, it becomes big challenges to connect from a region to another regions. No doubt that smooth logistics management is a critical hurdle for many online businesses in Indonesia (Velaasia, 2013). Logistic plays very important role in online businesses because it makes the process of items delivered to final e-commerce consumers faster. The challenges include the delivery of the purchased items on-time and ensure to cover most of the regions in Indonesia. According to the interview of Bede Moore, Co-Founder and Managing Director of Lazada Indonesia (Campbell, 2014), Indonesian courier performance is patchy and unreliable and On Time Delivery (OTD) is very low compare to other developed markets.

\section{Literature Review}

Management Guru Peter Drucker (2002) once said that: The truly revolutionary impact of the Internet Revolution is.. e-Commerce --- that is, the explosive emergence of the Internet as a major, worldwide distribution channel for goods, for services, and, surprisingly, for managerial and professional jobs. This is profoundly changing economics, market and industry structure, product and services and their flow; consumer segmentation, consumer values and consumer behavior, jobs, and labor markets. Nevertheless, the impact may be even greater in societies and politics, and above all, on the way we see the world and ourselves in it.

This paper is aimed to get online consumer insights of Lazada Indonesia as online retailing e-Commerce business. According to Turban et al. (2012), electronic commerce (e-Commerce) is defined as the process of buying, selling, transferring, or exchanging products, services, and/or information through computer networks, mostly the Internet and intranet. Further e-Commerce industry could also be classified by the nature of its transactions and relationship between the participants. It can be categorized as: Business-to-Business (B2B), Business-to-Consumer (B2C) that used by most of online retailing (e-Tailing), Business-to-Business (C2C), Business-to-Business-to-Consumer (B2B2C), Consumer-to-Business (C2B), Intrabusiness EC, Business-to-Employees (B2E), Consumer-to-consumer (C2C), Collaborative Commerce, and e-Government. Based-on that classification, Lazada Indonesia can be categorized as B2C e-Commerce or e-Tailing company.

Further, Turban also defines e-Tailing Business Model as a method of doing business by which a company generates revenue to sustain itself and achieve its goals and classified it based-on its models and distribution channels in online retailing. They are direct marketing by mail-order retailers that go-online, direct marketing by manufactures, pure-play e-tailers, click-and-mortar (brick-and-click) e-tailers, and Internet (online) malls/marketplace. The online consumer behavior model is divided by two major parts, which are derived from influential factors and the consumer decision processes. There are five dimensions that affect online consumer behavior in e-Commerce which consists of controllable variables and uncontrollable variables. Online consumer characteristics, environmental characteristics and merchant and intermediary characteristics are uncontrollable variables, which means it cannot be changed or directly controlled by the seller. Product/service characteristics and e-Commerce Systems (technology and website variables) belong to controllable variables; therefore, the seller can modify those factors. The attitude-behavior decision process shows that online consumer attitude is 
The online consumer behavior outside Java Island: A case study of Lazada Indonesia

considered as a beginning time of the consumer decision process is started. A positive online consumer attitude can lead to intention to online purchasing behavior.

Consumers do shop online because they find more product choices. They can access many information before making decision. For busy consumer, they can save time and find shopping more convenient since online merchants serve their needs individually. Wide coverage access to information and mixed with lower operating cost for many Internet business may, in turn, drive the reductions in prices or improvements in quality. The concerns of convenience and speed seem to be the most obvious reasons why consumer prefer online shopping rather than traditional bricks-and-mortar method of shopping. Consumer have also been described as time-poor, thus desperate to spend their non-work time in more recreational pursuits as arguments for the growth and sustainability of online shopping (Parsons, 2002). Those papers were supported by a study conducted in 2004 by ACNielsen Research regarding the main reasons why consumers shop online.

According to Hanson (1999), the location, timing and buying process via the Internet are much exceptional than other traditional methods of buying goods and services. The long operational duration of online storefront up to 24 hours per day and can be accessed from anywhere makes online shopping more convenient to consumers and provides consumers with great alternative channel of making purchase. Another factor that influence consumer to shop online is promotion or special deals and competitive pricing strategy. Cheaper prices are offered to online shoppers because of competitive pressure, especially from new online retailers. New online retailers use price as a main competitive weapon to attract customers. Online retailers are able to offer cheaper pricing because of the shrinking cost of information processing, lower operating cost and global reach provided by the Internet (Rowley, 2000). At the other hand, convenience is the most prominent factor that motivates consumers to shop online. Good selection and wider availability of product choices offered by online retailers also motivates online consumers to purchase goods and services over the Internet (Harn et al., 2006). Online retailer can provide varied product assortments more simple than the traditional channels, because there is no limitation of physical space for placing product in their online stores. Compared to the previous researches above, this study wants to offer options to e-Commerce companies like Lazada Indonesia to be able to reach new target market geographically (in this case, outside Java island). It might be reached by understanding its consumer behavior and applying modern internet-based marketing techniques, which are expected to work efficiently, effectively and has not been used in the traditional marketing channels before.

\section{Methodology}

In-order to get the online consumer behavior insights, the case study was initiating a market survey, a market research technique in which a sample is interviewed in some form or the behavior of respondents is observed and described (Zikmund, Babin, Carr, \& Griffin, 2012). Online data collection was being used in this project considering many benefits and consequences, including: reducing cost, ease of data entry, format flexibility, and ability to access different populations make this type of data collection extremely appealing (Granello \& Wheaton, 2004). To address issues like measurement errors and non-representative sample, this project only applies internal company data of Lazada Indonesia and creates segmentation based-on the need of analysis. Next step, the analysis was done by utilzing statistical descriptive techniques to analyze overall result and present reliable decision outcome and the data in comprehensive way, so as the readers can easy understand visually. Further, Zikmund et al. (2012) argue that descriptive research describes characteristics of objects, people, groups, organizations, or environments. Some supporting data analysis could be presented by using picture, table, graph, chart and etc. Statistics answers questions by using data, or information about the situation; some of these answers do require numbers and formulas, but it could be also in the format of some pictures-graph, and tables (Stine \& Foster, 2011). The comparisons among the respondents could also be used to understand the unique characteristics of each consumer segmentation.

A market survey was conducted in May-June 2014, by the using of online questionnaire that was provided by Survey Monkey (www.surveymonkey.com) and applying Lazada Indonesia company's customer data as its 
respondents. The questionnaire uses direct option answer and Likert scales, as well as open-ended questions. Likert scales was classified from some classifications: strongly disagree (1), disagree (2), agree (3) and strongly agree (4). Additional factors which are barriers in online shopping were added to understand what kind of factor(s) that potentially becoming an issue or obstacle for customers to do online shopping. The barriers in online shopping questions were developed as an adoption from motivation in online shopping and this factor were intentionally added because it had been used in previous market survey at Lazada Indonesia.

The respondents were existing consumers who live in outside Java Island. There are two types of consumers. First, consumers who subscribe to the newsletter or become members in Lazada Indonesia and already made purchase, they are called as "customers". The second group is consumers who subscribe the newsletter or become members in Lazada Indonesia, but not yet purchase in Lazada Indonesia, and they are called as "non-customers". This criteria were applied to differentiate the profile and characteristic of consumers who already purchased and the one who have not purchased yet. The author who was worked at Lazada Indonesia distributed an email contains survey questionnaire-link to 1,000 potential receivers by using Mail Chimps (www.mailchimp.com), targetting only for those who match to the above survey criteria.

The test of reliability was applied to determine the consistency of the measuring instrument based-on questionnaire tools. The method that used on this test is calculating its Cronbach's Alpha. The data is valid when the reliability level of Cronbach's Alpha is $\geq 0.0746$ (Priyatno, 2012). In this project, online consumer behavior then analyzed by using the Online Consumer Behavior Model that considers some variables, such as: consumer characteristics, environmental characteristics, merchant \& intermediary characteristics, product/services characteristics, payment $\&$ logistics supports, website features and customer services. The question format was a combined open-ended questions whereby the customers can choose more than one answer, as well as Likert or scaling method that could measure some Online Consumer Behavior Model variables. Respondents also can give feedback for company improvements by filling-in the suggestion box provided at the end of this market survey.

\section{Results and discussions}

A total of 42 respondents obtained, consists of 18 customers and 24 non-customers respondent categories. The proportion was quite ideal even though non-customers have more participants. It can be justified good because the author who was working at Lazada Indonesia also targeted to attract new customers that come from existing customers who already subscribed Lazada newsletter but not yet making a purchase. Current customers' responses also important because the authors aimed to get insights from customer that already making a purchase. The questionnaire design can be seen in the Appendix A which also applies Likert scale measurement, consists of 20 variables. Based-on SPSS reliability test results, its Cronbach's Alpha test revealed that the data obtained from this market survey was quite reliable (0.827), since the reliability level is more than 0.07 .

The respondents' profile characterize in this online purchasing survey were dominated by males with $73.8 \%$ proportion, meanwhile the females' proportion was $26.19 \%$. However, this may not disturb the survey analysis because there will be male and female comparison analysis. Based on age, most of the respondent's age is above 20 years old, $33.33 \%$ respondents were in the range of 35-40 years old, and the rest of $7.1 \%$ respondents were aged below 20 years old. It means that most of the respondents were adult people. Most of the respondent's occupation were working people or professional employees. If the proportion of employee and entrepreneur is combined, it will result $76.1 \%$ proportion. College and high school students were only contributed around $23.7 \%$. It may support some arguments that most of online shoppers in this survey were people who are busy to work and they have sufficient income to purchase from their occupations. In terms of education level, $54.67 \%$ of respondents have a bachelor education level. The rests who have a diploma and high school education level contributed up to $42 \%$, and only $2.38 \%$ respondents had a junior school education. Based on that finding, it shows that majority of online shopper respondents were well-educated, at least higher than high school. The respondents' income level in outside Java island are mostly below USD 400. However, the 'middle-income' respondents who have salaries ranging from USD 600 - USD 800 can be considered as quite promising because 
it has more than $10 \%$ proportion.

The profile of respondents in outside Java Island were between 20 to 40 years, had occupations as an employee or entrepreneur and had finished their bachelor degree. It means, most of online shoppers were adult who have job or own business and have high education level. Most of their income were below USD 400 which means at that income level they are ready to shop online. At the other hand, based-on this survey, a numbers of people who use mobile-phone and tablet were almost similar to PC/Mac/Laptop users because the difference is only $9 \%$. It means that the growth of mobile-phone usage in outside Java Island can be considered as quite significant as the smartphone penetration may increasing as predicted by experts.

The most contributing factors that motivates consumers in the outside Java Island to shop online was to shop anywhere and anytime (3.28 mean score for customers and 3.59 mean score for non-customers). Compared to the previous similar research conducted by Lazada Indonesia in February 2014 towards 65 respondents, that concluded that respondents choose saving time factor as the main reason for shopping online. It might be happened because of the difference of respondent's locations. The second motivational factor was saving time and many product choices factor (3.00 mean value for customers and 3.45 mean score for non-customers) while availability of Cash on Delivery payment method was in the third rank (3.17 mean score for customers and 3.27 mean score for non-customers). Based on this findings, it led to the premise that most of online shoppers were busy people who want simplicity and hassle-free shopping. They do not have many times or do not willing to spend more times to walking through many traditional shops which may spend their times more. Moreover, online shopping becomes their purchasing method alternatives, because it can be accessed anytime and anywhere as long as they have the Internet connection.

The biggest barrier factors in online shopping were that they can't see and touch the purchased items $(3.28$ mean score for customers and 3.27 mean score for non-customers), then it followed by payment security/fraud issues ( 3.00 mean score for customers and 3.05 mean score for non-customers) and the uncertainty that the purchased items will be delivered or not (2.94 mean score for customers and 2.82 mean score for non-customers). Besides those factors, as for customers, they were concerning more in the long delivery time (3.11 mean score) while non-customers were more concerning about the payment security or fraud (3.05 mean score). Fashion was the most demanding product categories for both customers (61.1\%) and non-customers (77.3\%). It has also became favorable product category for males $(65.5 \%)$ and females $(81.8 \%)$. However, non-customers-females had more willingness to purchase fashion compared to customers-males. The second favorable product category for males $(62.1 \%)$ were mobile phone and tablet. As for female, home appliances (54.6\%) was the second favorite product category.

Bank transfer still became the most preferred payment method $(77.8 \%$ for customers and $72.7 \%$ for non-customers), followed by Cash on Delivery (55.6\% for customers and $59.1 \%$ for non-customers) and Internet banking payment method (33.3\% for customers and 31.8\% for non-customers). Not many Indonesian people own credit cards, therefore most of them are using bank transfer as their common payment method. However, the intention to use credit cards may increase, especially for non-customers (18.2\%) who choose to use credit card compared to customers (11.1\%). There was positive feedback for Cash on Delivery payment method, since most respondents were demanding more coverage areas for Cash on Delivery. As for another payment method, none of respondents $(0 \%)$ choose PayPal and Payment Gateway payment methods. Outside Java island customers were eager to spend more money for online shopping compared to their non-customers. Most of customers (38.9\%) were willing to spend USD 40 to USD 80 while most non-customers (40.9\%) spend from USD 20 to USD 40. It means that outside Java island consumers who had experience before in online shopping were willing to spend higher amount compared to those who did not have online shopping experience before. The overall perception of respondents towards the product characteristics offered by Lazada Indonesia was quite good with some notes. Unfortunately, only reputable brand and high quality products that got appreciations by the respondents. In terms of e-Commerce Systems (technology and website variables), the respondents gave good evaluation, especially with the payment method of Cash on Delivery. Customer service and pricing had the 
lowest score of evaluation from respondents. According to the customers' feedback, expensive shipping cost became one of the respondents' main concerns.

Social Media had strong influences in purchasing decision making both for male (58.6\%) and female (90.9\%) respondents. Even, Social Media were chosen by $90.9 \%$ female as their references before they shop online. The second influencer for females was family/friend (63.6\%) while the second influencer for males was blog review (55.2\%). Overall, online media influences most of the respondents. $61.54 \%$ respondents was referred by search engine, it means Search Engine Optimization (SEO) may play as important roles to attract more visitors. Social Media and search engine ads were also chosen by more than $40 \%$ respondents. Only few respondents were influenced or referred by non-online media or medium, except, family/friend that have $25.64 \%$ proportion, it was bigger than TV ads, radio ads and print ads.

\subsection{Recommendations, implications and limitations}

Based-on the findings and discussions from the previous section, the authors may propose the following recommendations and implications to the Lazada Indonesia company. This insights may also useful for those who are particularly engaging in this online business industry especially to develop the market outside Java Island. As for advertisement efforts, the e-commerce players shall consider in placing ads based-on the right targeted or segmented audiences, typically for those who are adult enough (age of 20 to 40 years old), well-educated (at least finished high school education level) and having job or own their businesses. To support this effort, the company should maximize the use of mobile/digital marketing that uses mobile applications, chatting channels (LINE, Kakao Talk, Blackberry Messenger channel) to respond the growth of people who access the Internet from their smartphones. Therefore it is expected also to accommodate people to shop anytime and anywhere (any device) much easier. It is also recommended to use additional tagline in the marketing messages to overcome consumers who worry about the payment security or fraud. For instance, emphasizing the wordings such as: "Safety Shopping" ("Belanja Aman" in Indonesia language) on the right channels of Search Engine Optimization (SEO), Affiliate, Search Engine Marketing (SEM), Content Marketing and Social Media. Actually the use of current tagline "Effortless Shopping" ("Belanja Gak Ribet" in Indonesia language) is very good because it follows Lazada Group' corporate standard.

In response to higher demand in fashion product categories, it would be advisable to maximize the use of Social Media that play important roles as influencer and reference. Especially for females as the audience who really interest in this product category. It needs "extra push" or good campaign like what Lazada Indonesia had done in some mobile phone and tablet or electronic products. Moreover, Lazada should increase the number of fans, followers, and utilizing Social Media networks to catch up with another competitors. This efforts is aimed to attract customers to report their purchase in Lazada Indonesia when they alredy receive the product they purchase, therefore it will increase User-Generated Content (UGC) created by the utilization of Social Media. Prizes strategy for customers may stimulate them to share their shopping experiences in Lazada Indonesia. To overcome online shopping barrier of "can't see and touch the item", Lazada should ensure the delivery of product information, contents, descriptions; photos and videos (if any) are well-embedded in each product offered. One of the examples is fashion products that require more details and traditionally people need to see and touch or try it before purchase it. As for fashion product like shoes, Lazada had already created shoe size measurements. Sufficient product information will make consumers become confident enough to make decision to purchase.

As for payment method, it is advisable that Lazada Indonesia continue the cooperation with well-reputable banks and credit card providers to create special deal for customers. Competitors like Blibli.com and Bhinneka.com have popular campaign that cooperate with well-reputable banks such as: "BCA Klik Pay Deal Belanja Serba IDR 10,000" (any item purchased equal to USD 0.80 in Indonesia language and currency) and "Harga Rebutan Mandiri" ("seizure price" in Indonesia language). Lazada Indonesia shall benefiting from the increasing of credit cards usage and banks that promote their payment system alternatives for online shopping. It 
The online consumer behavior outside Java Island: A case study of Lazada Indonesia

shall increase the coverage areas for Cash on Delivery (COD) payment method, since many customers request the availability of COD in their areas. It also can be used to reduce consumers' concern on payment security or fraud and for those who feel uncertain if their purchased items will not be delivered as expected. COD payment method may reduce those concern feelings because consumers don't have to take risk to lose his money and time due-to any failures happened in the electronics payment system. Consumers only pay directly to the couriers when the purchased item is arrived or delivered. This effort support previous research which found that Indonesian people tend to like COD and logistics companies who are more open towards COD (TechinAsia, 2013). Moreover, Lazada Indonesia should increase COD coverage areas because they are still lagging behind among other Lazada Group companies in Asia.

In-order to increase its awareness, Lazada Indonesia should improve its community and customer engagement by conducting more activities, such as: gatherings, sponsoring and involving communities and customers to give more positive contributions to Lazada Indonesia. Strong community and good engagement are one of the key success factor of its competitor Kaskus.co.id to maintain its visitors and keep Kaskus' Forum Jual Beli (buy and sell forum) alive. Some recommended activities to get more engagements with customers and communities incluing company visits, guest lecturing, seminars, and create scholarship programs and partnerships with varied communities. As for customer review program, Lazada Indonesia may adopt Write and Win program like what has already done by Bhinneka.com.

Lazada Indonesia may also build research and development team to analyze market trend and online consumer behavior since the online consumer behavior, market trend and competitions will keep changing from time-to-time. It can be useful to respond every changes on trend and to continue understand what online consumer needs and wants. Based on the research findings that have already discussed in the previous section, this study might leave some practical implications that the digital marketing methods such as the use of Search Engine Optimization, Search Engine Marketing, Content Marketing and Social Media are good tools to enable to reach or expand the new target market geographically. And this strategies would play in a more important role in future online retailing industry, like Lazada Indonesia, therefore the e-Commerce companies may need some expertises in this particular area. As consequences, social variables also might become another major influential factor initially triggered by the growing numbers of social media network subscribers as well as become an interesting discussions in online marketing research, especially in the area of online consumer behavior. Online consumers might become more significantly influenced by family members, friends, and cowokers. Thus, customer endorsement as well as word of mouth marketing will be found in the forms of Internet communities and discussion groups that communicates through chat rooms, tweeting or news groups. Considering that this study uses a more descriptive statistical methodology to get the insights from customers and non-customers categories, therefore more complex methodology such as multivariate research design and bigger samples are highly suggested by authors to explore more rigorous findings to get more accurate online consumer behavior insights. Finally, the authors hope that this study will benefiting and balancing both practical and academic interests, especially for e-Commerce or online business experts and industry players in common.

\section{References}

Ahniar, N. F. (2011, January 5). Di provinsi mana pekerja digaji tinggi? [Which provinces the workers are paid with high salary]. Viva News. Retrieved from http://bisnis.news.viva.co.id/news/read/197633-di-propinsi-mana-pekerja-digaji-tinggi-

Asosiasi Kartu Kredit Indonesia. (n.d.). Graph illustration on credit card number, credit card transactions number, and credit card transactions value. Credit Card Growth. Retrieved from http://www.akki.or.id/index.php/credit-card-growth

Asosiasi Penyelenggara Jasa Internet Indonesia. (2015, March). Profil pengguna internet Indonesia [Indonesia internet user profile 2014]. Retrieved from https://apjii.or.id/downfile/file/PROFILPENGGUNAINTERNETINDONESIA2014.pdf

Badan Pusat Statistik-Statistic Indonesia. (2010). Graph illustration on population pyramid of Indonesia. Sensus 
Winarko, H. B., \& Manshur, A. T.

Penduduk 2010 [Citizen census 2010]. Retrieved from https://sp2010.bps.go.id/

Badan Pusat Statistik-Statistic Indonesia. (2012, May). Consumption expenditure. Trends of the selected socio-economic indicators of Indonesia. Retrieved from

https://www.bps.go.id/publication/2012/11/23/4a731ca8f86ef8096ac7d2c6/perkembangan-beberapa-ind ikator-utama-sosial-ekonomi-indonesia-mei-2012.html

Barber, N., Dodd, T., \& Kolyesnikova, N. (2009). Gender different in information search: Implications for retailing. Journal of Consumer Marketing, 26(6), 415-426. https://doi.org/10.1108/07363760910988238

Bodnar, K. (n.d.). Amazing SEO infographics. Retrieved from http://blog.hubspot.com/blog/tabid/6307/bid/6442/12-Amazing-SEO-Infographics.aspx

Campbell, P. (2014, January 22). Entrepreneur profile: From Harvard to Indonesian e-Commerce with Bede Moore. Power retail. Retrieved from

http://www.powerretail.com.au/insights/entrepreneur-profile-harvard-indonesian-e-commerce-bede-mo ore/

Central Intelligence Agency. (2014). East \& South East Asia: Indonesia. In The world factbook. Retrieved from https://www.cia.gov/library/publications/the-world-factbook/geos/id.html

Charlesworth, A. (2009). Internet marketing: A practical approach. Butterworth-Heinemann.

Crespo, A. H., \& Bosque, I. R. D. (2010). The influence of commercial features of the internet on the adoption of e-Commerce by consumers. Electronic Commerce Research and Applications, 9(6), 562-575. https://doi.org/10.1016/j.elerap.2010.04.006

Crunchbase. (2014). Lazada group. Retrieved from http://www.crunchbase.com/organization/lazada-group

DeMers, J. (2014, January 8). The three pillars of SEO in 2014. Forbes. Retrieved from http://www.forbes.com/sites/jaysondemers/2014/01/28/the-three-pillars-of-seo-in-2014/

Drucker, P. (2002). Managing in the Next Society. New York: Truman Talley Books.

Econsultancy. (2010, November 9). New eCommera report unveils inconsistent measurement of e-Commerce profitability across the board. Retrieved from

https://www.econsultancy.com/press-releases/5274-new-ecommera-report-unveils-inconsistent-measure ment-of-ecommerce-profitability-across-the-board

Emarketer. (2013, August 2). Smartphone penetration doubles in Indonesia: Nearly one-quarter of the population owns a smartphone. Retrieved from

http://www.emarketer.com/Article/Smartphone-Penetration-Doubles-Indonesia/1010102

Granello, D. H. \& Wheaton, J. E. (2004), Online data collection: Strategies for research. Journal of Counseling \& Development, 82(4), 387-393. https://doi.org/10.1002/j.1556-6678.2004.tb00325.x.

Grant, R. (2013, December 9). Amazon clone Lazada raises jaw-dropping \$250M to mainstream e-commerce in Southeast Asia. Venture Beat. Retrieved from

http://venturebeat.com/2013/12/09/lazada-raises-jaw-dropping-250m-to-mainstream-e-commerce-in-so utheast-asia/

Hanson, W. (1999). Principles of internet marketing. Ohio: South-Western College Publishing.

Harn, A. C. P., Khatibi, A., \& Ismail, H. b., (2006). E-Commerce: A study on online shopping in Malaysia. Journal of Social Sciences, 13(3), 231-242. https://doi.org/10.1080/09718923.2006.11892554

Lazada. (n.d.). Cara mengetahui cakupan area COD \& pengiriman gratis [How to know COD coverage areas \& free delivery]. Retrieved from http://dilazada.blogspot.co.id/2017/04/cara-mengetahui-cakupan-area-cod.html

Lazada. (n.d.). Informasi pengiriman [Shipping information]. Retrieved from http://www.lazada.co.id/shipping/

Lukman, E. (2013, October 28). 6 facts that you should know about cash-on-delivery in Indonesia. Tech in Asia. Retrieved from http://www.techinasia.com/facts-cash-delivery-indonesia/

Mannisto, L. (1999, March 18). Electronic E-Commerce in Asia. Paper presented at the International Telecommunication Union Asia and the Future of the World Economic System, London.

Margherio, L., Henry, D., Cooke, S., Montes, S., Hughes, K. (n.d.). The emerging digital economy. Retrieved from http://www.esa.doc.gov/sites/default/files/emergingdig_0.pdf

Marketeers Magazine. (2013, November). Indonesia Netizen survey 2013. Available from 
The online consumer behavior outside Java Island: A case study of Lazada Indonesia

https://ebooks.gramedia.com/id/majalah/marketeers/nov-2013

Mohammed, R., Fisher, R. J., \& Jaworski, B. J. (2003). Internet marketing: Building advantage in the networked economy. Cornell University: McGraw-Hill.

Moz. (n.d.). What is domain authority. Retrieved from http://moz.com/learn/seo/domain-authority

Page, L., Brin, S., Motwani, R., \& Winograd, T. (1998). The PageRank citation ranking: Bringing order to the web. Stanford University.

Parsons, A. G. (2002). Non-functional motives for online shoppers: Why we click. Journal of Consumer Marketing, 19(5), 25-39.

Porter, M. E. (2001). Strategy and the Internet. Harvard Business Review 79(3), 62-78.

Porter, M. E. (2008, January). Competitive forces that shape strategy. Harvard Business Review. Available from http://hbr.org/2008/01/the-five-competitive-forces-that-shape-strategy/ar/1

Priyatno, D. (2012). Belajar cepat olah data statistic dengan SPSS [Statistical data processing quick learning with SPSS]. ANDI Publisher Yogyakarta.

Rastogi, V., Tamboto, E., Tong, D., \& Sinburinsit, T. (2013, March 5). Indonesia's rising middle-class and affluent consumers: Asia's next big opportunity. The Boston Consulting Group. Retrieved from https://www.bcgperspectives.com/content/articles/center_consumer_customer_insight_consumer_produ cts_indonesias_rising_middle_class_affluent_consumers/

Rowley, J. (2000). Product search in e-shopping: A review and research propositions. Journal of Consumer Marketing, 17(1), 124-135. https://doi.org/10.1108/07363760010309528

Sharma, M. (2013, August 13). Rocket Internet's Lazada builds out its marketplace model, while Europe fashion portal Zalando gets a new investor. Techcrunch. Retrieved from http://techcrunch.com/2013/08/13/rocket-Internet-regional-expansion/

Stine, R., \& Foster, D. (2011). Quantitative methods for business. Statistics for business: Decision making and analysis. Pearson Education.

Sugden, S. (2013, June 12). Indonesian e-commerce market size to double in 2013 to US\$8B. E27. Retrieved from http://e27.co/indonesian-e-commerce-market-size-to-double-in-2013-to-us-8b/

Supriyanto, B. (2013, April 9). E-Commerce Lazada perluas gudang sistem logistik [Lazada e-Commerce expands logistic system warehouse]. Koran Bisnis. Retireved from http://industri.bisnis.com/read/20130409/105/7513/e-commerce-lazada-perluas-gudang-sistem-logistik

The World Bank. (2014). Graph illustration on country score card Indonesia: 2014. International scorecard. Retrieved from http://lpi.worldbank.org/international/scorecard/radar/254/C/IDN/2014\#chartarea

Turban, E., King, D., Lee, J., Liang, T. P., \& Turban, D. (2012). Electronic commerce 2012: A managerial and social network perspective ( ${ }^{\text {th }}$ ed.). United States: Pearson.

Vela Asia. (2013). Help needed: one in four Indonesian Internet users reject ecommerce because of bad logistics. Retrieved from http://www.velaasia.com/one-in-four-indonesian-Internet-users-reject-ecommerce-because-of-bad-logist ics/

World Population Review. (2014). Indonesia demographics 2014. Retrieved from http://worldpopulationreview.com/countries/indonesia-population/

Zikmund, W., Babin, B., Carr, J., \& Griffin, M. (2012). Business research methods $\left(9^{\text {th }}\right.$ ed.). US: Cengage Learning. 
Winarko, H. B., \& Manshur, A. T.

Appendix: Questionnaire Design

\begin{tabular}{|c|c|c|}
\hline Variables & Question Type & Measurement \\
\hline Gender & Multiple choices (only one answer) & Male/Female \\
\hline Age & Multiple choices (only one answer) & $\begin{array}{l}\text { Less than } 17 \text { years old, } 17-20 \text { years old, } 21-24 \text { years } \\
\text { old, } 25-30 \text { years old, } 35-40 \text { years old, more than } 40 \\
\text { years old }\end{array}$ \\
\hline Education & Multiple choices (only one answer) & $\begin{array}{l}\text { Elementary School, Junior School, High School, } \\
\text { Diploma, Undergraduate, Post Graduate and } \\
\text { Professor }\end{array}$ \\
\hline Occupation & Multiple choices (only one answer) & $\begin{array}{l}\text { High School Student, College Student, Employees, } \\
\text { Entrepreneur, Housewife }\end{array}$ \\
\hline Cultural & Multiple choices (only one answer) & Province in outside Java Island \\
\hline \multirow[t]{5}{*}{ Income } & Multiple choices (only one answer) & USD 0 - USD 200 \\
\hline & & USD 200 - USD 400 \\
\hline & & USD 400 - USD 600 \\
\hline & & USD 600 - USD 800 \\
\hline & & More than USD 800 \\
\hline \multirow[t]{4}{*}{ Habit } & Multiple choices (only one answer) & Less than 1 hours \\
\hline & & 2 hours \\
\hline & & 4 hours \\
\hline & & More than 6 hours \\
\hline \multirow[t]{3}{*}{ Lifestyle } & Multiple choices (only one answer) & Desktop PC / Laptop / Mac \\
\hline & & Feature phone (Nokia Asha, Symbian, Java) \\
\hline & & Smartphone (Android, iOS, Blackberry) \\
\hline Online Shopping Experience & Multiple choices (only one answer) & Yes/No \\
\hline Community & Single textbox & Online Community \\
\hline Shopping Preferences & Multiple choices (only one answer) & Online/Offline \\
\hline \multirow[t]{8}{*}{ Online Shopping Motivation } & Saving time & Likert Scale (XM1) \\
\hline & Shop anywhere anytime & Likert Scale (XM2) \\
\hline & Many product choices & Likert Scale (XM3) \\
\hline & Cheaper price & Likert Scale (XM4) \\
\hline & Complete product information & Likert Scale (XM5) \\
\hline & Fast delivery & Likert Scale (XM6) \\
\hline & Complete payment method & Likert Scale (XM7) \\
\hline & Free shipping & Likert Scale (XM8) \\
\hline \multirow[t]{9}{*}{ Barriers in Online Shopping } & Don't know to shop online & Likert Scale (XH1) \\
\hline & Slow Internet Connection & Likert Scale (XH2) \\
\hline & Can't find the item & Likert Scale (XH3) \\
\hline & Price more expensive & Likert Scale (XH4) \\
\hline & Can't see and touch item & Likert Scale (XH5) \\
\hline & Long time delivery & Likert Scale (XH6) \\
\hline & Unsure item will delivered & Likert Scale (XH7) \\
\hline & Payment security/fraud & Likert Scale (XH8) \\
\hline & Expensive shipping cost & Likert Scale (XH9) \\
\hline Shopping Preferences & Multiple choices (more than one answer) & Choose Online Store \\
\hline Product Preferences & Multiple choices (more than one answer) & Choose Product Category \\
\hline Purchasing Power & Multiple choices (only one answer) & Amount to be spend for online shopping \\
\hline Informational Social Influence & Multiple choices (more than one answer) & Choose Media or Reference \\
\hline Payment Method & Multiple choices (more than one answer) & Choose payment method \\
\hline \multirow[t]{4}{*}{ Lazada Reputation } & Product & Likert Scale (XE1) \\
\hline & Price & Likert Scale (XE2) \\
\hline & Information and content & Likert Scale (XE3) \\
\hline & Brand & Likert Scale (XE4) \\
\hline \multirow[t]{7}{*}{ Lazada Valuation } & $\begin{array}{l}\text { Complete Payment Method include Cash On } \\
\text { Delivery }\end{array}$ & Likert Scale (XE5) \\
\hline & Website Navigation & Likert Scale (XE6) \\
\hline & Product Information & Likert Scale (XE7) \\
\hline & Accessibility & Likert Scale (XE8) \\
\hline & Customer Service & Likert Scale (XE9) \\
\hline & Refund or Return Guarantee & Likert Scale (XE10) \\
\hline & Order tracking & Likert Scale (XE11) \\
\hline
\end{tabular}

